\title{
Koreans of The South Ussury in 1879
}

\author{
Sergey V. Tkachev ${ }^{1}$ \\ Sergey V. Ryazantsev² \\ Natalia N. Tkacheva1 \\ ${ }^{1}$ Far Eastern Federal University \\ 2Institute of Social and Political Studies of the Russian Academy of Sciences \\ E-mail: riazan@mail.ru
}

\section{Doi:10.5901/mjss.2015.v6n3s4p121}

\section{Abstract}

This article presents a demographic analysis of the Korean population in the region during its initial development, family composition, and marital relations between Koreans and Chinese. The study statistically confirmed the consequences of a number of historical events in the region, as well as a local manifestation of the effect of 'Missing Women of Asia' among the Korean population in the period under study. It is possible to say that such a powerful historical source as the research work of Vislenev on the "foreign" population of the South-Ussuri region was for the first time subjected to a comprehensive study. We hope it will be widely introduced into the scientific research. The results obtained, in our opinion, can significantly expand our understanding of the first settlers in the territory of the Russian Far East, but also of technologies for adaptation of migrants in the new location as a whole.

Keywords: Koreans, South Ussuri region, relocation, demographics, geographical location.

\section{Introduction}

Aigun (1858) and Beijing (1860) Russian-Chinese agreements allowed to Russian Empire acquiring of large areas of the Eastern Manchuria, known as the South-Ussuri region. The acquired territories' pressing administration issues required adequate data on their population. Then the first question that raised was - how many people live here, and what they do. In studying the historiography of this issue it can be seen that the data in a sufficiently general form has been provided by N.Przhevalskiy, Kafarov (arch. Palladium) M.Venyukov, Alyabiev, G.Budischev, L.Shrenk and others. One of the deepest studies of the region called "Koreans and foreigners of the South Ussuri region" has been conducted by a senior officer on special assignments at the administration of the Eastern Siberia, a Court Counselor Vislenev in 1878-1879 (Inorodcheskoe naselenie Priamurskogo kraya, 1884).

Modern researchers often refer to the study of Vislenev, but only to his generalized data on the number of nonRussian population given at the very beginning of his work. The fact is that in contrast to the works of the authors mentioned above, the study of Vislenev is quite extensive statistical review. Its analysis is very time-consuming. In addition, there is some distrust to this source, and it requires a thorough verification.

However, the data presented in the study of Vislenev are very interesting. It is unique, scientifically based demographic information on non-Russian population of the South-Ussuri region in the early period of its modern settlement; a rare in its completeness source which practically has not been involved yet in the scientific research. In the present study we aime at evaluating these data and in case of a positive answer on their validity, to perform the first statistical analysis of the current situation with "foreigners" in the region.

First, we checked out the source on errors and typos. Secondly, we have reconstructed the survey route and have localized the "foreign" phases that Vislenev passed and sequentially numbered. Third, based on the survey, a database has been created, which included a geographical location of "foreign" population of the South-Ussuri region, a list of names, and family and professional relationships within a household.

The history of Koreans in Russia is of interest to researchers since a long time. However, we see noticeable resurgence of public interest in the last few decades. There are several reasons for that. One of them is the establishment of diplomatic relations between the USSR and the Republic of Korea in 1990, which significantly intensified the institutionalization of the local Korean community; another one - the collapse of the Soviet Union, accompanied by, in 
particular, the relocation of Koreans from the Central Asian republics to Russia, and, respectively, the desire to understand the complex history of Koreans in Russia and their place in it.

A number of works devoted to this subject has been recently published (Saveliev, 2010; Lee, 2012 \& Tkachev, 2010). In addition, the topic is actively discussed in the context of understanding of the mass deportations during Stalin's time (Naimar, 2010). "Koryo Saram-- unreliable people", a Korean documentary film is also worth mentioning (Chung, Matt Dibble \& Meredith Jung-En, 2006). Of course, the migration of Koreans in the former Russian Empire are also of interest in terms of the general theory and practice of migration, particularly emerging in the new millennium (Ryazantsev, 2013 \& Mishchuk, 2013).

According to the works of Korean researchers, the history of migration of Koreans from the Korean peninsula to Russia before the revolution of 1917 has several periods (Chzhon, Bon Su. 2011, p.173). The first period of migration (1863-1884) is mainly related to the economic difficulties of the peasants on the peninsula. And if the Joseon Dynasty, ruling at that time, somehow prevented their peasants resettlement to Primorsky region of Russia, the Russian side did not show strong opposition to this relocation, bearing in mind the need for development of virgin lands.

The second period (1884-1894) begins with the signing in 1884 of the joint trade treaty expiring in 1894. Shortly after the second wave of resettlement the attitude of the Russian Empire toward the emigration of ethnic Koreans from the Korean peninsula has changed for the better.

The third period lasted from 1894 to 1910. In 1894, there was the Tonhak peasants' rebellion in Korea. This period is characterized as a period of politically motivated resettlement of immigrants. Starting 1910 Japan controls the entire Korean peninsula. According to this chronology, our study refers to the first stage of the migration of Koreans to Russia.

The appearance of the first Korean settlers in the Russian territory is described in detail in (Pak, 1993 \& Petrov, 2000). There is some disagreement in this event's dating. Some researchers are of the opinion that it happened in 1863 , others - in 1864. According to Kuhner " the first Korean settlers came to the Primorsky region in 1862 or in 1863 (in 1861 there were no Koreans in the new Russian region) (Kyuner, 1912). Recall that the first Russian settlement in the SouthUssuri region appeared after the signing of the Aigun agreement in 1858. This relocation was due to the extreme lack of lands in North Korea, forcing farmers to fight for survival. As a result, any cataclysm led to mass starvation. "A small amount of arable land (an average of 0.5 tithes per person), its poor performance, due to its low quality, is the reason that in the country, despite the hard work of its inhabitants, there is no surplus in cereal products, the residents have barely enough food to feed themselves" (Bayov, 1904).

After joining the South Ussuri region of the Russian Empire, the Koreans had a chance to change the conditions of their life. Starting 1863-1864 the first Korean families began to relocate to the Posiet and Suyfun regions where they organized several settlements (Sedimi, Tizinhe, Yanchihe, Adimi, Korsakovka, Putsilovka, Sinelnikovo). According Budishchev, who described the forest of the Posiet region in June 1867, "The Koreans arrived here recently, but sow bread and vegetables, although their first winter was destitute. From their ploughed fields that I have seen and the convenience of the location, I believe that the Koreans will have a lot of bread and live a good life"(Lesa Priamurskogo kraya, 1883, p. 361).

A vilage of Korean "fangzi" houses in the South-Ussuri region looked like their traditional settlements in Korea. "In the extreme north-east (of North Korea) villages are largely a series of extremely scattered fāngzi' $s$, in which they live in groups of 1 to 2 and rarely of 3 families. As we move to the south-west, villages become more compact, consisting of 2 - 3 groups of fairly significant number of fāngzi' s located closer to each other ... 5 to 6 persons usually live in every household here, from time to time the number of inhabitants of a household reaches 10 people " (Bayov, 1904). (It is worth noting that our geo-information and statistical data analysis of Vislenev's study gives almost the same distribution). In the works of Korean researchers we find quite detailed information about the construction principles of traditional rural households and housing technologies (Oh Hong-seok, 2009), which in the South-Ussuri region differed little from those that were established in North Korea.

However, the immediate cause of the mass transition was the hunger of 1869. This migration was spontaneous and was accompanied by a very significant number of deaths. "In the fall of 1869 , when North Korea suffered serious flood, and afterwards strong frost, which destroyed crops, a new, massive relocation of Koreans gone with the terrible hunger began into the Russian territory.... In late September - early October 1850 Koreans (1300 men and 550 women) came to Tizinhe without warm clothes and food stocks... In late November - early December 18694500 Koreans suddenly crossed the border.... Later it turned out that during the entire year of 18696543 people crossed the Russian border (3533 men and 3010 women, one third of them were children) (Pak, 1993). According to the official data, in 1870 3750 Koreans were settled in the territory of South-Ussuri region. Losses should be attributed to a death of hunger and the further transition of settlers to Manchuria, where they were settled by the Chinese authorities (Pak, 1993). 
That is how the history of appearance of Koreans in Russia is given by different historical sources. However, there are several statistical studies made by the Russian administration in the territory of the South-Ussuri region and directly connected with the situation study of Koreans. They are the above-mentioned data of the expeditions of N.Przhevalsky, M.Venyukov, G.Budischev and others. However, the most complete study is Vislenev's "Koreans and foreigners of the South-Ussuri region" dated 1878-1879. The report of Vislenev was submitted in 1880 and published with small reductions in 1884 by the decision of D. Anuchin, the governor-general of the Eastern Siberia. The report presented in tabular form 1879 foreign population census data per capita of the Ussuri region, namely: national origin and belonging to the Orthodox Church, sex, age, full name, year of arrival to the Ussuri region, home location, family and professional relationships between inhabitants of a particular house (fāngzi), belonging of households to villages, and the data on perfamily turnover of agricultural land not included in the published report (only a summary over all the districts was presented). The report covers 481 pages and gives information on 1039 fāngzi' s scattered throughout the territory of about $80000 \mathrm{sq} . \mathrm{km}$.

Our aim here was to verify the report of Vislenev and if the report's data accuracy is confirmed, to analyze the socio-demographic situation among the Korean population of the South-Ussuri region at an early stage of their relocation to the region.

\section{Methods and Sources}

In the XIX and early XX centuries the methods of collecting information were already used. They were similar to the modern ones; in terms of methodology it is modern research, however, there were no modern data processing methods, primarily machining. Sociological studies were often very extensive, but presented in tabular form, they did not allow a deep analysis of their results - all mathematical analysis was limited to the summation or an approximation in case of insufficient data.

In this respect, a statistical overview of Vislenev provides an excellent opportunity for a fresh look at the life of the first foreign settlers of the Primorsky region. However, there is some distrust to this source. It is mentioned by Ivan Nadarov, Colonel of the General Staff, who arrived to the South-Ussuri region a year after Vislenev left it: "Several times I heard from people, that the statistical census of foreign population of the South Ussuri region, carried out by Vislenev in 1878 and 1879, does not deserve any trust on the grounds as if all his work had been made in Vladivostok, from his office" (Nadarov, 1886).

However, I. Nadarov himself - one of the founders and active participants of the "Society for the Study of the Amur region," - said that the data of Vislenev is quite reliable and gives his proofs:

1) 'Speaking as someone who took many of Vislenev' s paths, I always heard from Manzi about the Vislenev ' s census. Checking his tables, at every step I was convinced of the correctness of their contents, including the names of fāngzi landlords...” ;

2) “... Mister Vislenev in his statistical tables has exactly mentioned the places where fāngzi' s were really located" ;

3) the accuracy of Vislenev's data has been confirmed by the "assessor" of the Suchan area, Prince Kropotkin, as well as by Oshurkov, the "assessor" of Posiet area, and by Zanadvorov, the Head of Suyfunsk County (Nadarov, 1886).

4) According to the data of Budishchev, who studied the region in 1861-1865, in the most populated Khankaisky and Suchansky regions there were 212 Chinese fāngzi' s; in these regions Vislenev (1879) recorded 209 fāngzi landlords, who arrived to the regions before 1860. Two studies conducted at different times, give similar results confirming each other. "This gives even greater soundness to Vislenev's studies" (Nadarov, 1886).

Of course, the first thing that catches the eye, it is the scale of the study and, by the same time, its very limited time frame ( 1 year). The study has been conducted on the villages closed to the riverbeds and the seacoast. Of course, it could not fully describe all the foreign inhabitants of the region, but it covered the vast majority of them, since Chinese, Koreans, local Aborigines and Russians preferred these landscapes for compact settlement. But even with this limitation, Vislenev had to take (probably on foot, on horseback and by boat) a route of, according to our calculations, approximately $3787 \mathrm{~km}$ (without considering his way back) (Figure 1). This is a very large distance even by the modern standards, with the modern system of communications. 


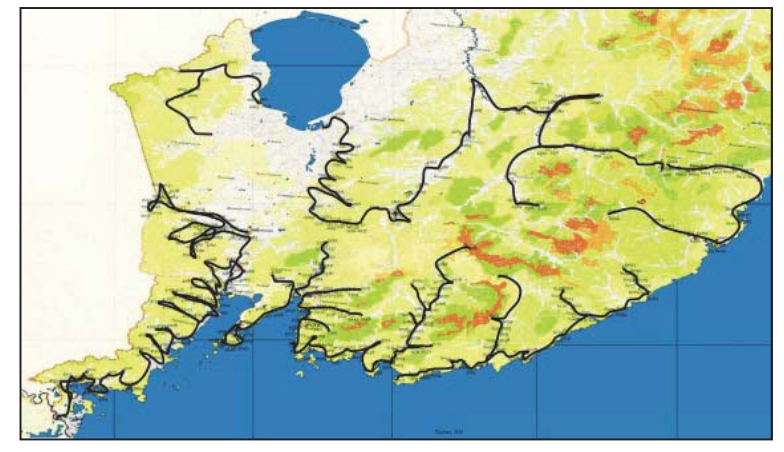

Figure 1. Vislenev's routes while studying foreigners in South-Ussuri region (1879)

However, after a thorough analysis of the source, it can be said that the data given in it are not a "cabinet work" of Vislenev, but the result of a real, very labor-intensive and extensive research. In this article we will not give a complete proof of this argument. We mention only the names non-repeatability, accuracy of his routes' description (often with distances that differ from those calculated on the geographical maps of that time), data correspondence to little-known historical events, of which Vislenev was hardly aware, etc. Its credibility is confirmed by the errors that the survey contains. The unique possibility to make a study of that level is to break an expedition into 5-6 groups headed by reliable Vice Heads, experienced guides and interpreters.

One could also assume that the study has been conducted over several years. However, on each of the routes there were people, who arrived to the Russian Empire in 1879. Therefore, it can be concluded that the survey expedition was entirely conducted in that year. Apparently, Vislenev had considerable financial resources and the ability to simultaneously survey on different routes using one methodology. That increases even more the importance of his research of foreign population of the region.

Before to start our study, we have attempted to determine the authenticity level of Vislenev's report.

Firstly, the source has been checked for mistakes and omissions. They turned out to be quite a lot. For example, the total amount of Koreans in the South-Ussuri region included only those who lived in Korean villages, but did not consider those, who lived in separate fāngzi' s (400 persons - 10\% of the total). There was an error in the calculation of the total as well. We have tried to fix it.

However, there were some errors that could not be corrected. In some (very minor) cases Sino-Korean families were described with common children of over 16 years old (under 40 years old). This is unlikely, since for a variety of historical reasons, these families could be formed only after 1863 - the year when the first Koreans left their homeland. Before that year, it was also unlikely to create such families in Manchuria. Apparently, they were not their native children, but adopted ones. Anyhow, the problem lies in the fact that in the tables the "adoptees" were specifically marked, and they were a lot (51 persons in 1879 according to Vislenev). However, our assumption is confirmed by the fact, that among those "too aged children" the men were dominating (as well as among the "adoptees", girls were under the age of 18).

In addition, there are several cases in the tables, when the years of arrival to the South-Ussuri region follow each other in a certain repeated sequence. Most likely, these data suggest the dishonesty of the interviewer or of the person who has processed the results. However, for our study those nuances are not critical.

Secondly, we have reconstructed the route of Vislenev and, based on his description, accurately localized the fāngzi' s he passed and sequentially numbered. This work proved to be very time consuming. The main problem here lied in identifying hydronyms that, to our time, often changed its name several times. Vislenev localized fāngzi' $s$ along the rivers or the seacoast with respect to each other in miles and, in addition, periodically added the distances to any noticeable points either through the main routes, or by a straight line on the map.

We often experienced problems. To identify the places we used our numerous historical maps and descriptions of places. When that did not help, we used the "countdown", when a geographically defined point was found within a route (usually at the intersection of several locations), the way back was reconstructed in the opposite direction. Published in 1883 the study "Description of forests of the Maritime region" of Captain Budishchev, whose routes in 1859-1867 were often similar to the ones of Vislenev, also has helped in some cases. QGIS 2.0 Dufour, which combines historical and contemporary maps, as well as geographic analysis, has been used for the localization of fāngzi's.

Finally, based on the survey of Vislenev, a database has been created including: geographical location of "foreign" population of the South-Ussuri region, names, family and professional relationships within a household. In this work we 
present some results of the performed analysis.

In general, we can say that, despite the inaccuracies, typographical errors, negligence in collection of the data, we do not doubt the accuracy of the data of Vislenev's expedition. Moreover, as a result of statistical analysis, we found indirect evidence of some historical events, to which our attention will be given below. Since a large amount of data has been analyzed, to forge such statistics would be extremely difficult.

So, we came to the conclusion that in 1879 the Court Counselor Vislenev conducted a large and qualitative social research, the results of which may have a scientific value.

\section{Results}

In total in 1879 the South-Ussuri region had a population of 6378 Koreans (3445 men and 2933 women). Overall, the gender and age structure (Figure 2) is sufficient for the harmonious sex ratio, taking into account the fact that it describes a resettlement community: number of women is less than number of men. It is clear that the Koreans resettled in families. However, the gender imbalance is still sensitive - about 15\%. In reality, this ratio is even higher, since 130 Korean women were married to Chinese (see below). This imbalance changes over time. According to 1915 census data (i.e., 36 years after the study of Vislenev), among the Korean population of Nikolsk-Ussuri county, where the most part of the Korean population of the South-Ussuri region was concentrated, among the "ascribed" ( that is, who had their own plots of land) Koreans having Russian citizenship, men were only $2.5 \%$ more than women. At the same time, in "non-ascribed" and in Koreans having foreign citizenship men were $27.7 \%$ more than women (Naselennye I zhilye mesta Primorskogo rayona, 1915). However, the last indicator was apparently influenced by political factors. In other words, as the Korean peasant community settles in a new land, it becomes more stable.

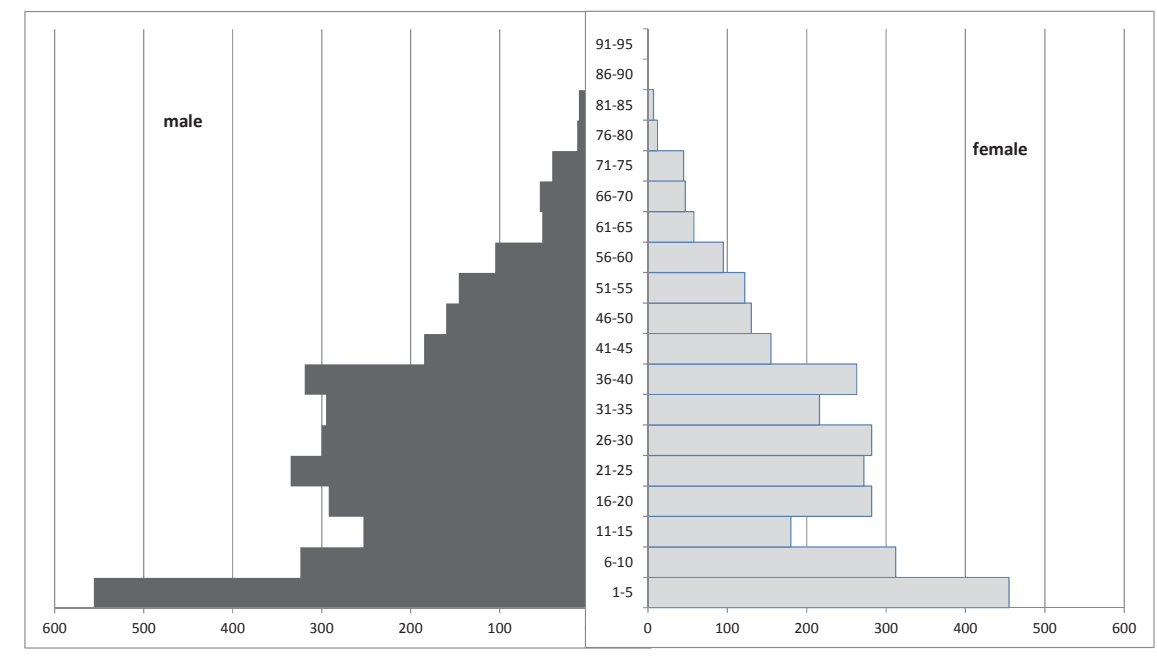

Figure 2. Age and sex structure of the Korean community in the South-Ussuri region in 1879: 3445 men, 2933 women, mean age -26.88 years

This situation is in stark contrast to the structure of the Chinese community of the South-Ussuri region of that time, where there were no Chinese women at all (Figs. 3-4). In general, this situation with the Chinese population of the region is very unique and requires further analysis. Russian historiography believes that the Chinese in the South-Ussuri region were "migrant workers", i.e. seasonal migrants. The data of Vislenev rather say that it was not true (at least, in 1879). The Chinese, who are not in Vladivistok, say they arrived to the region a few years (or many decades) before 1879. For example, two (of 979) Chinese fāngzi owners (Te Chow Ying and Li Guang) say they arrived in 1820. And only three of them - in 1879.

On the other hand, the age and sex structure of the Koreans is similar to the demographic structure of Russian (Ukrainian) immigrants (Figure 5). The latter is very balanced, although this group has been created largely spontaneously. In both cases, it is focused, fundamentally the final migration of socially formed communities and families. 


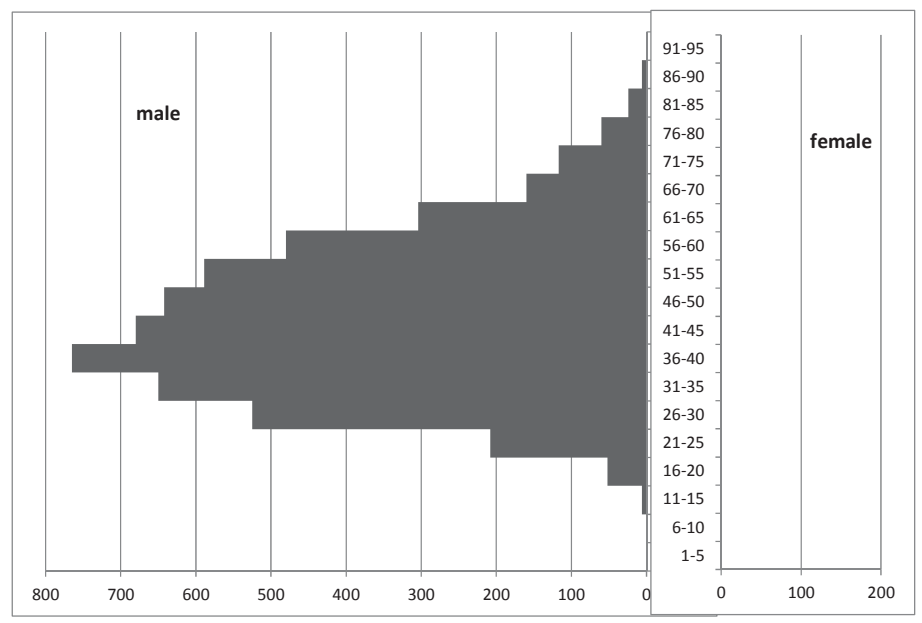

Figure 3. Age and sex structure of the Chinese community in the South-Ussuri region (without Vladivostok) in 1879: 5268 males, mean age 44.98 years

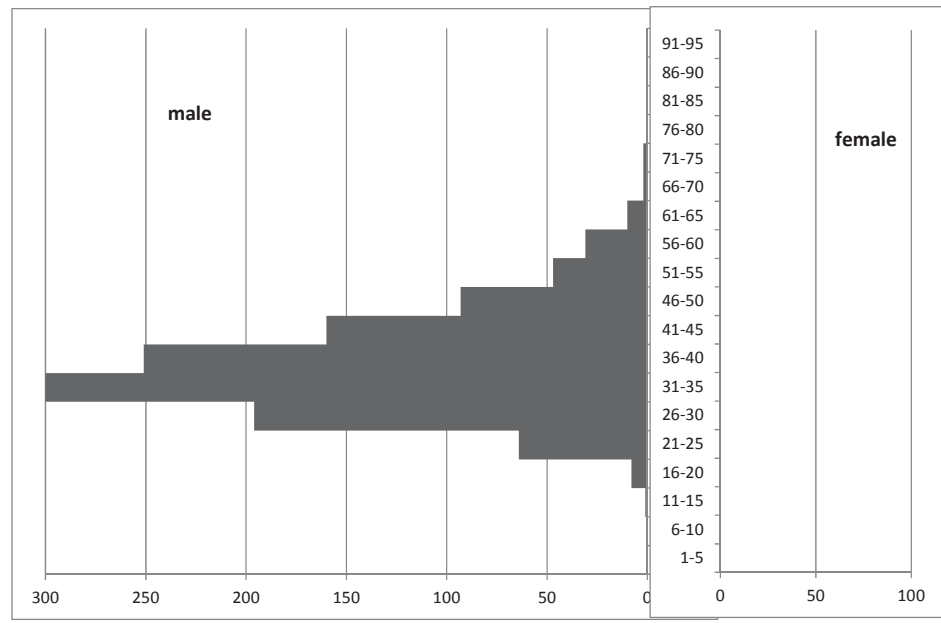

Figure 4. Age and sex structure of the Chinese community in Vladivostok in 1879: 1165 men, mean age is 37.05 years

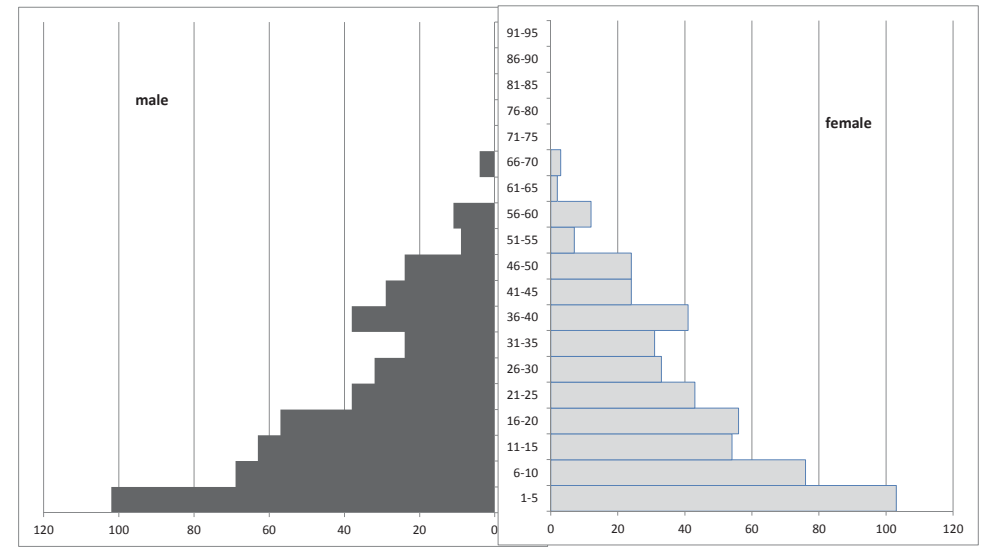

Figure 5. Age and sex structure of migrants from Chernigov province, arrived by sea to the South-Ussuri region in 1883 Estimated based on (Pereselenie russkich lyudey v Priamurskiy krai, 1884). 501 men, 509 women, mean age is 21.37 years. 
As it can be seen in the reduced age-sex pyramid above (Figure 2), its structure is violated by the deficit of 11 to 15 years old population, i.e., born in 1864-1868 years. We consider this problem in more detail, while taking into account that the Koreans could bring already born children to their new settlement.

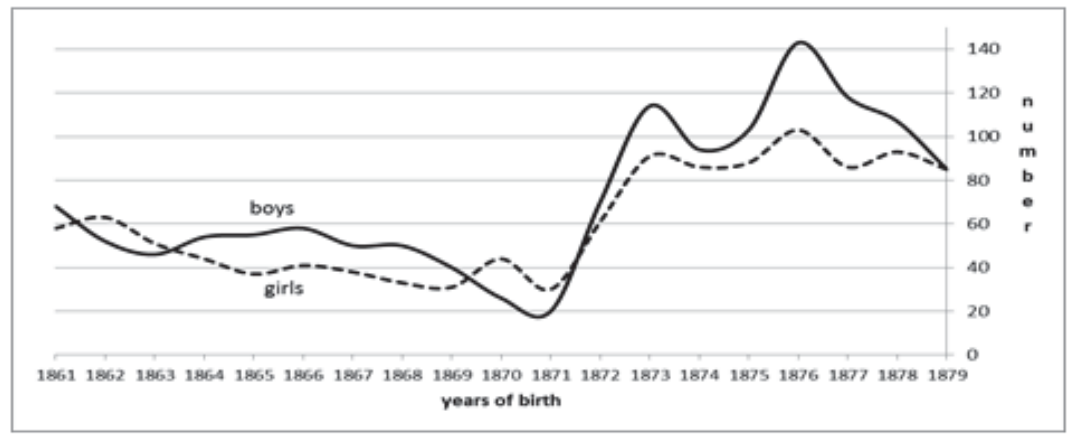

Figure 6. Number of Korean children in the South-Ussuri region in 1879, by year of birth

Figure 6 shows that the decline in fertility was observed in 1871, while in 1869-1870 there was an uncommon excess amount of born girls over boys. According to different sources, that time is a period of mass migration of Koreans accompanied by the enormous deaths of hunger and executions of deserters. At the same time Korean soldiers killed all the men and boys, women and girls were released (Pak, 1993). Vislenev's statistical data for newborns within this period confirms this fact - there were more girls. It should also be taken into account, that in extreme conditions (hunger, stress) the survival ratio of fetus and female infant is even higher, than the one of male infant in normal conditions.

However, no single Korean women have been recorded by the census, and in only five cases the fāngzi owners (exclusively in the Korean villages) were the widows of 45, 32, 27, 23 and 20 years old with their children. We wonder what happened to the other women and girls? Perhaps some of them went back to Korea to their remaining relatives. Some stayed. But in this case they had to join a family. However, in the lists of Korean families made by Vislenev we do not find any foreign women (girls could be adopted, and in this case we would not have been able to identify them).

We find "missing"Korean women in the territory of South-Ussuri region as Chinese wives. It is known that the Chinese ("Manzi"), who moved to the region, were men only (the relocation of Chinese women to the other side of the Great Wall of China was strictly forbidden until 1878). Therefore, the appearance of "free" women immediately entailed the establishment of Sino-Korean families.

In 1879, there were 130 such families in the South Ussuri region. According to Vislenev's records, Korean women in these families were wives and not concubines. Moreover, the structure of those records (and of other similar records made by Russian statisticians of that time) assumes a formal distribution of status roles in relation to the eldest within the household (of course, from the point of view of the interviewer). The names of fāngzi owners were immediately followed by the names of their wives, right after them - their common children and "adoptees" inheriting a household, and then associates, employees, other inhabitants and their families. It seems, that such a situation is fully consistent with the idea of Richard Wrangham that "the need for a man to have a wife in order to provide himself with food is a universal rule among hunter-gatherers. Food seems to more influence man's decision to get married, than a need for a sexual partner" (Wrangham, 2009, p.75).

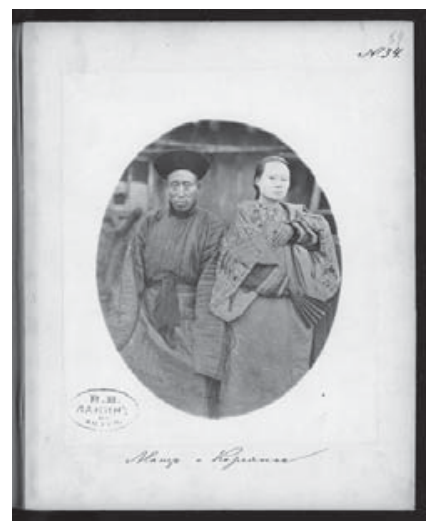

Figure 7. Manza and Korean. Photo of V.V.Lanin (70s of XIX century, South Ussuri region) 
There were no "free" Korean women, which could be interpreted as concubines in Chinese fāngzi' s. Apparently, Korean women enjoyed great popularity among Chinese men compared with Aboriginal women (Figure8.). There were far fewer Sino-Taz families, and young Potuyzes (born in Sino-Korean families) almost always chosen wives among Korean women.

\begin{tabular}{|c|c|c|c|c|c|}
\hline Women Men & Chinese & Koreans & Potuyzes (Koreans) & Taz & Potuyzes (Taz) \\
\hline Chinese & 0 & 0 & 0 & 0 & 0 \\
\hline Koreans & 125 & 17 & 14 & 5 & 9 \\
\hline Potuyzes (Korean) & 5 & 1 & 0 & 0 & 0 \\
\hline Taz & 60 & 5 & 8 & 87 & 25 \\
\hline Potuyzes (Taz) & 1 & 0 & 0 & 0 & 5 \\
\hline
\end{tabular}

Figure 8. Interethnic relationships outside of compact residence of the Korean settlers. According to the terminology of Vislenev, Potuyzes are descendants of mixed marriages. Here "Potuyzes (Korean)" are descendants of Chinese-Korean marriages, and "Potuyzes (Taz)" are descendants of the Chinese-Aboriginal marriages

Based on those data, we can say that there was a formal monogamy within Sino-Korean fāngzi's (which is completely natural given the shortage of women), although we cannot exclude "passing a woman for a while". In general, considering the statistics of Vislenev on such households, it seems that the Chinese tried to create a family, with the possibility of transferring the accumulated property to descendants (if there were no any, they took "adoptees"), providing themselves care in old age and (which is important for religious grounds in the eastern nations) after death.

Demographic analysis of the descendants of the Sino-Korean marriages is of our particular interest. Among those "Potuyzes" there were 154 men and 109 women, some of them should have been "adoptees".

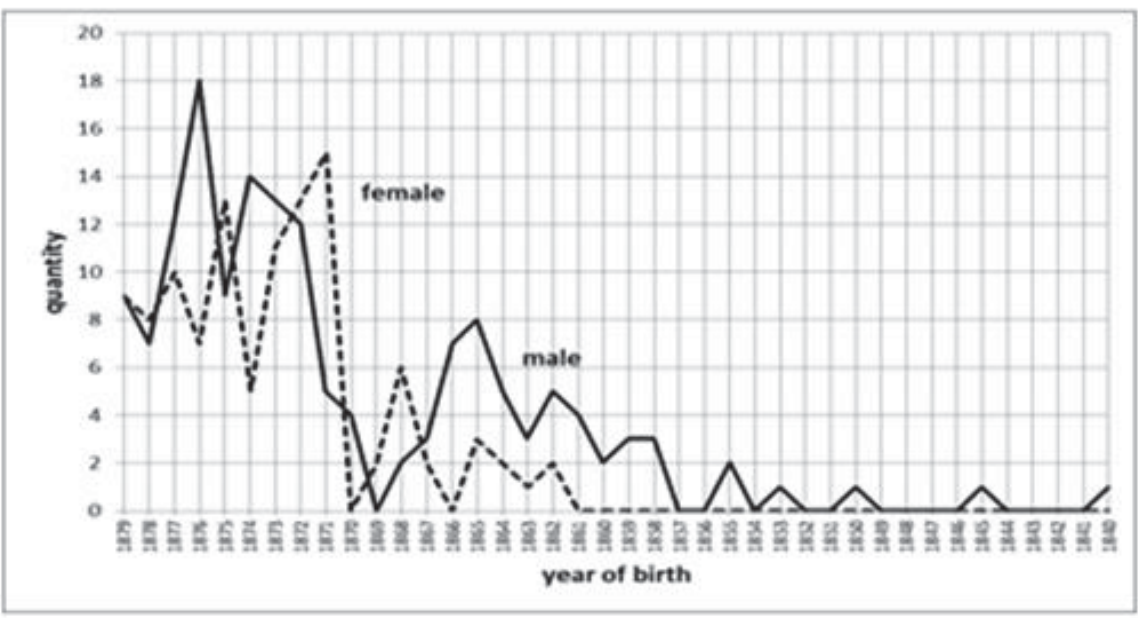

Figure 9. Number and year of birth of children in the Sino-Korean families of the South Ussuri region in 1879

Despite the slight quantitative expression of this process, the above graph shows that:

1. Single Chinese accepted mostly Korean boys and young men to their households as "adoptees"; among them there were no Korean girls who were born before 1861; it is also difficult to fix the adoptees - natives of the indigenous population (though in the latter case it was possible to change the name, and for an interviewer they may be represented as "Manzi").

2. A spike of adoption of girls to Manzi families was recorded in 1868, apparently, simultaneously with a marriage to a Korean mother; at the same time the number of adopted boys decreases (to 0 in 1869). This confirms that Korean men and boys were killed during their transition through Tumangan river to Russia.

3. Starting 1870 , we observe a sharp spike in the appearance of "Potuyzes", probably already common children of Manzi and widowed Korean women.

4. Unusual excess of the number of newborn girls over newborn boys in 1871 could confirm either continuing 
widows' (with daughters) admission to Manzi families, or the hunger and other shocks that affect a male fetus heavier, than a female one.

In general, the majority of Koreans prefer to settle in a compact way (Figure 10). Settling represented in this figure on the basis of later collected data, mostly repeats the situation, which was observed by Vislenev in 1879. There is difference in a wider distribution along the border and in the population of Vladivostok.

In the Posiet department (Figure 10 - Yanchihinskaya and Adiminskaya parishes) in 1879 the Korean settlements are almost exclusively monoethnic. However, further north along Suyfun river (Razdolnaya) and Suchan river (Partizanskaya), the situation changed:

a) Chinese workers appear in the Korean settlements.

b) Mixed Korean-Chinese villages appear, when Korean fāngzi's were built next to Chinese ones, while, paradoxically, they somehow had a separate management.

c) Korean villages (Suchan) emerge among Chinese villages and individual fāngzi's.

By the same time, interethnic marriages were rare. For Pokrovskaya and Borisovskaya parishes - 15 Chinese (all fāngzi owners) married to Koreans out of 162 Chinese fāngzi's. Note that here the maximum distance between Korean village and Chinese fāngzi, whose owner was married to a Korean, is $13 \mathrm{~km}$ (usually up to $5 \mathrm{~km}$ ).

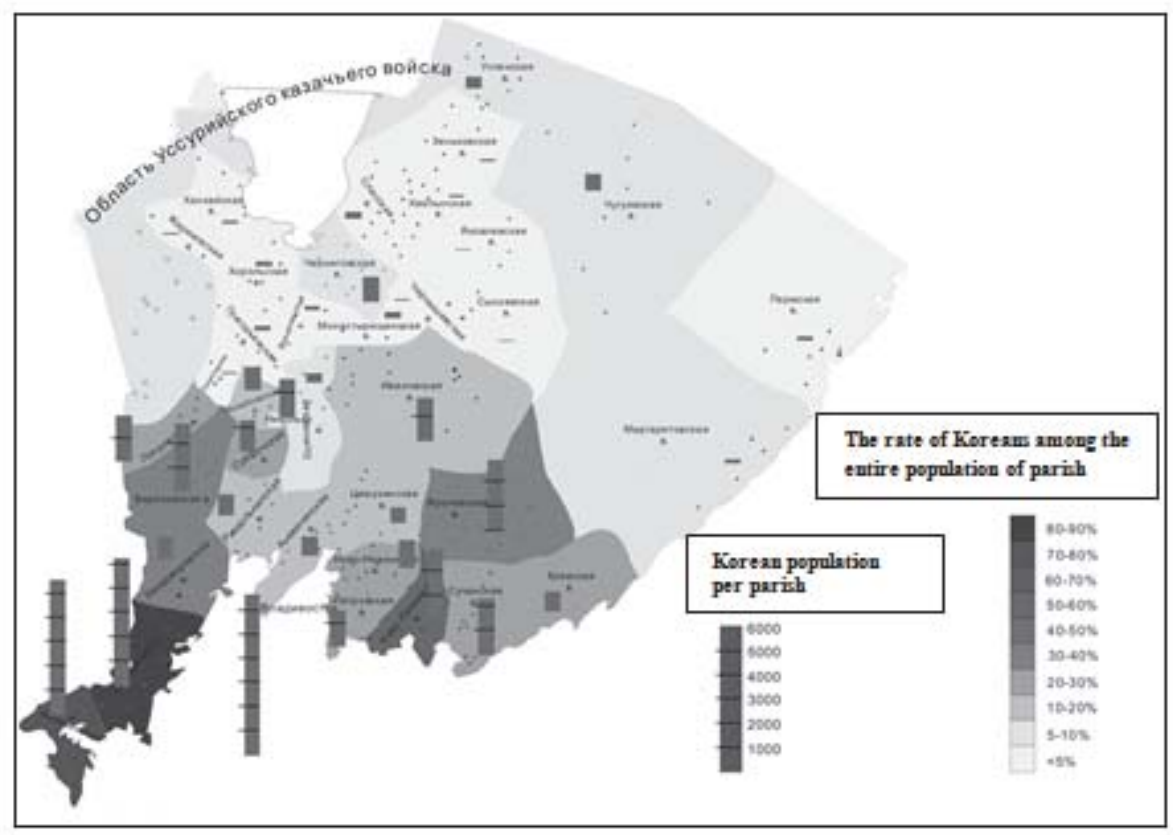

Figure 10. Number of Koreans in the South-Ussuri region (1907)

Thus, they were marriages between neighbors. A woman could maintain contact with her relatives. In Avvakumovsk district adjoining the North-Ussuri region, the situation is different. The population denisty here is lower, and the distance between Korean and Chinese fāngzi, whose owner was married to a Korean, can reach $225 \mathrm{~km}$. In spite of the distance from the areas densely populated by Koreans, there are 23 Sino-Korean (Chinese and aboriginal) marriages out of 168 non-Korean fāngzi's. In absolute terms and relatively - it's greater, than in areas densely populated by Koreans.

Figure 11 shows that, in general, the farther from Korea, the more the Chinese decided to get married, choose a local woman from the natives, and that is understandable. But in any case, the number of married Chinese is extremely small here. According to Vislenev's data, in the region in 1879 there were only 191 such Chinese out of a total of 6408, i.e. less than 3\%. In Vladivostok there were only two married Chinese men (both to Korean women) out of 1200 Chinese adults $(0.17 \%)$. There is no constant tension observed among Manzi, natural in such a situation. Maybe, it is just the opium, which is very widespread among the Chinese and Aboriginal, when consumed regularly, suppress sexual desire. 


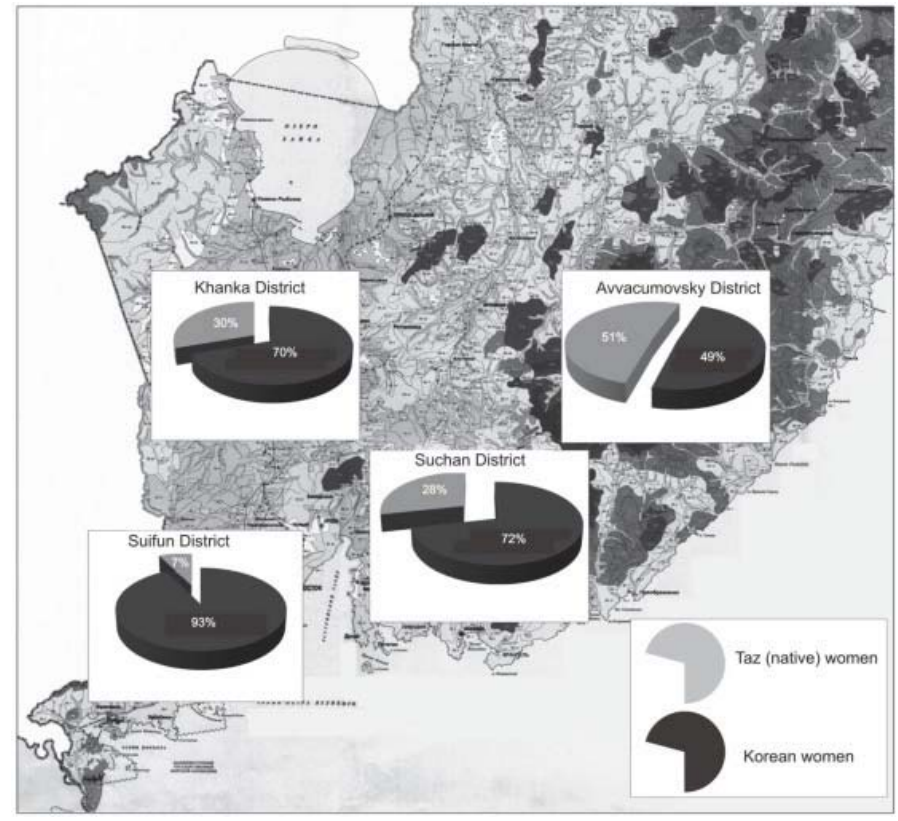

Figure11. Matrimonial choice of Chinese men in the South-Ussuri region for 1879

And yet, for the East Asians having a son is still the most important culturological constant. It is known that the current shortage of women in the region is about 100 million. It is believed, that this is due to special traditional expectations from a boy as family successor and guardian of spirits of the ancestors. For example, in Korea "Confucian beliefs require that everyone raises a male descendant (son), who will be responsible for taking care about the soul of his father after his death. Therefore, people who had no sons, sought to adopt any of the relatives of the younger generation. Adopted boys were considered as natural children of adopters inheriting their property, rights and privileges" (Ionova, 1960).

Among Koreans, this tradition is popular today. In 1990, the gap between the number of boys and girls among newborns reached a record level: 116/100. In certain areas, for example, in Daegu city, known for its patriarchal and ultra traditional morals, the gap was even greater. In 1988 in Daegu there were 100 baby girls for every 136 (!) baby boys. In general, it is in the more conservative provinces of the southern part of the country that the gap between the number of boys and girls is especially great. In May 1994, the Ministry of Health of South Korea forbade doctors to find out the sex of the embryo. The doctor who violates this prohibition shall be deprived of the license for 12 months. Repeated violation of the prohibition leads to a life-long deprivation of practicing medicine (Lankov, 2015, http://lankov.oriental.ru/203.shtml). This is the so-called effect of 'Missing Women of Asia'. The Vislenev's study also shows that.

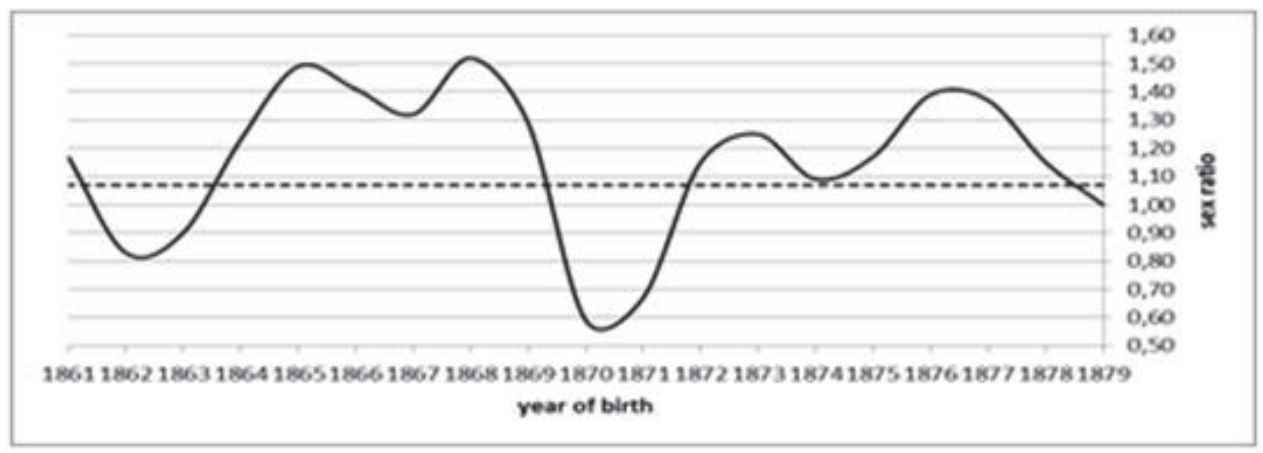

Figure 12. Sex ratio among Koreans of 0 - 19 years old in the South-Ussuri region in 1879. The horizontal line is the average value of the ratio at birth and up to 14 years old in the world today - 1.07 (from 15 to 24 years old - 1,062) (The world factbook, https://www.cia.gov/library/publications/the-world-factbook/fields/2018.html, 2014) 
Figure 12 shows that in the Korean settlements of the South-Ussuri region there were few years, when the number of peer-boys was $52 \%$ more than the number of girls (today's global birth rate - about 4\%, in modern South Korea - $7 \%$, North Korea - 5\%, China - 11\%). In general, if we assume that all Korean children of South-Ussuri region born after 1864 were born here, then the excess of the number of boys over girls would amount to 20\%. But if today (at least until 1994) the control over the birth of girls in South Korea is achieved through selective abortion, in the XIX century, there were probably other mechanisms, in particular, insufficient care about them in infancy.

As it can be seen in Figure 5, among the Russian settlers that trend was not clear. In the following groups of migrants one could observe some asymmetries in favor of male children, but for other reasons. Since the relocation was very difficult and needed, first of all, "man's hands" (even children's ones), the original settlers divided their family: head of a family with his wife, his younger brothers and sons were the first to come. As it established, the mother of the head of the family with her granddaughters and the wives of his younger brothers with their children joined them. (This is, of course, a general, common case). As a result, the number of boys and girls was becoming equal.

In addition, families of Russian and Korean settlers differed sharply in "nephews". In the first case we observe children of a brother of a head of a family occasionally, in Korean fāngzi's it is a very broad phenomenon. This phenomenon is explained in ethnography. "The responsibility of the father's brother included providing money for his nephew's wedding organization, buying him a house and a land. If the uncle was unable to support his nephew, he had to accommodate the family of the nephew at his place"(Ionova, 1960).

Vislenev's census also gives an idea of the age of marriage of the Korean women.

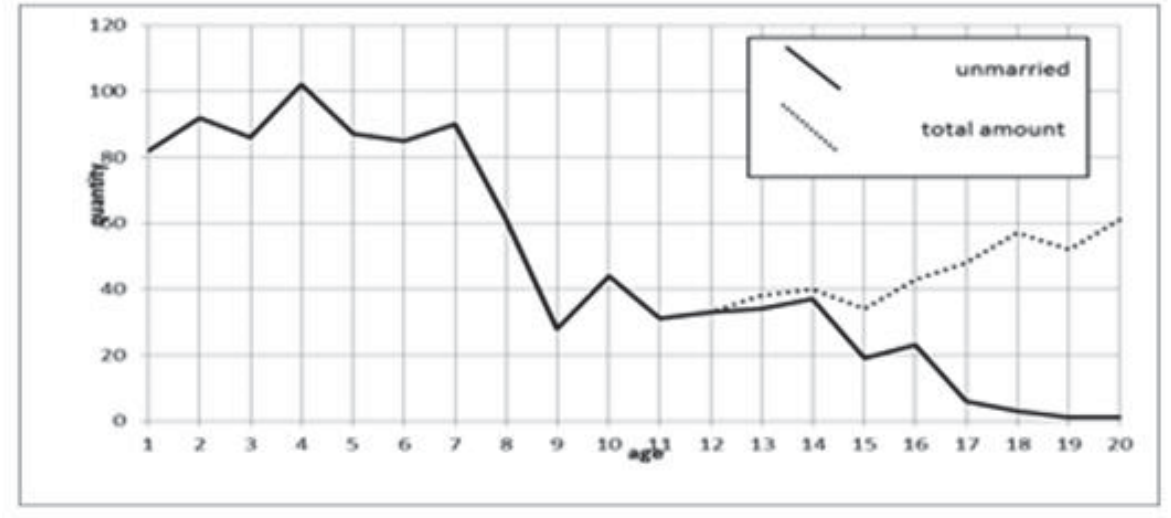

Figure 13. The number of unmarried women in the Korean villages of the South -Ussuri region and the total number of Korean women of up to 20 years old in 1879

Figure 13. show that girls got married in most cases at the age of 15 to 17 years old. In the census data we find several cases, when 13 years old Korean women were recorded as wives. In addition, there were one 25 years old and one 32 years old unmarried women living in families with parents or uncle, respectively. In any case, unmarried girls over 18 years of age are exceptions. Figure 13 clearly shows the crisis of 1869-1870, which once again proves the accuracy of Vislenev's data.

According to Yu lonova, in Korea "the laws in 1894 defined the legal age of marriage for girls at the age of 16 and boys at the age of 20, but early marriage also existed, when a boy of 12 years of age got married to a girl of 16-18 years of age" (Ionova, 1960). This fact is confirmed by the observations of travelers in Korea (Azbelev, I.P. 1895). In the territory of the South-Ussuri region such cases have not been recorded by Vislenev.

\section{Conclusion}

In general, the report of Vislenev gives a totally unique material not only for the study of Korean settlers in the SouthUssuri region, but also of Korean society of the second half of the XIX century. On the other hand, it was not possible to verify the credibility of that source without detailed consideration of the whole work presented in it. In our opinion and based on some direct and indirect proofs, despite the impressive breadth of Vislenev's report, it has a very high level of credibility.

Below we conclude with some issues concerning the independent existence of the Korean community in the 
South-Ussuri region.

Koreans relocated in families. Gender imbalance, which has been observed in the group of first Korean settlers, leveled off over time. Given the traditional monoethnicity of Korean men in marriage of that time (despite the 15\% shortage of women in the Korean community, according to the census, there were no any Korean-Aboriginal woman marriage, although among the Chinese, it was a common practice), we assume that "bringing" brides from Korea was very common.

Apparently, marital relationship of migrants differed from the traditional one in Korea. The changing nature of matrimonial behavior during migration is a natural phenomenon and is common in other diasporas as well (Ryazantsev, Pismennaya, Karabulatova \& Akramov, 2014). The report does not detect early marriages to older girls, which was largely a matter of raising the status of a minor husband. While adapting to a new environment, a family of that type was too costly. Question of the status was not the most important one. In general, the adaptation process had general and local features typical to border areas (Karabulatova, Koyche \& Gultyaev, 2013). The researchers note the transformation of language and culture during the migration process, which contributes to the expansion of the research community's national worldview [Karabulatova, 2013; Karabulatova \& Polivara, 2013 \& Ryazantsev, 2014.).

In 1879, there were 130 Sino-Korean families in the South-Ussuri region. According to Vislenev's records, we conclude that Korean women in those families were just wives, not concubines. In addition, apparently, compared to Aboriginal women Korean women enjoyed greater popularity among Chinese men. There were less Sino-Aboriginal families, and the adolescents coming from Sino-Korean marriages almost always chose wives among Korean women. Based on those data we colnclude that there was a formal monogamy in family Sino-Korean fangzi's. Apparently, the Chinese tryed to create a family, with the possibility of transferring the accumulated property to descendants (if there were no, they adopted), thus insuring care in old age, and (according to religious reasons) after death.

In general, the majority of Koreans preferred to settle in a compact way. In Posiet area, which is the closest to Korea, in 1907 up to $90 \%$ of the population were Koreans. However, the further north we go, the situation varies considerably. Here we find mixed Korean-Chinese villages, where Korean fāngzi's were close neighbors of Chinese ones, while, paradoxically, they somehow had a separate management.

While processing Vislenev's data, the significant excess of boys over girls in the Korean community (for some years peer-boys turned out to be $52 \%$ more than girls) has been observed. In our opinion, here we have a historical reflection of the 'Missing Women of Asia ' effect. However, we do not have any information about control mechanisms over the number of girls in our case.

As a result of the analysis of Vislenev's census, we have obtained valid data on the age at marriage of Korean women. We have found that girls got married in most cases at the age of 15 to 17 years. In general, in the Korean community unmarried woman of reproductive age is an extremely rare phenomenon: we found only one 25 year old and one 32 year old women living in families of parents and uncle, respectively; as well as five widows (45, 32, 27, 23 and 20 years old) with their children, who were fāngzi owners (only in Korean villages).

We have found some interesting facts about the Chinese community of the South-Ussuri region. Our attention is drawn to the age structure of this group, the presence of an unexpectedly high number of elderly men, the system of adoption of Korean boys, interethnic marriages, social relations, the distribution of names, etc. This will be the subject of our future research.

The article prepared within the RFBR grant, № 15-06-02854, "Economic-mathematical modeling of social reserves Russia's demographic development: a systems approach".

\section{References}

Inorodcheskoe naselenie Priamurskogo kraya. Sbornik glavneyshich ofitsialnych dokumentov po upravleniyu Vostochnoy Sibiriyu. Tom IV. Vipusk 2. Koreitsy i inorodtsy Yuzhno-Ussuriyskogo kraya Primorskoy oblasti. Irkutsk, 1884.

Saveliev, I. 2010. Mobility Decision-Making and New Diasporic Spaces: Conceptualizing Korean Diasporas in the Post-Soviet Space. In the: Pacific Affairs, Vol.83, No.3. pp. 481-504.

Lee, W. 2012. The Koreans' Migration to the Russian Far East and Their Deportation to Central Asia: From the 1860s to 1937, Graduate School of the University of Oregon.

Tkachev, S. 2010. Modernisation in Ussury Region (mid. XIX - beg. XX centuries): History, Methodology and Sources of Research. In the: Studies of Landscape History on East Asian Inland Seas: Research Institute for Humanity and Nature, Kyoto, Japan. pp. 2332.

Naimar, N. 2010. Stalin's Genocides. Princeton, NJ: Princeton University Press, 2010.

Chung, D., Matt Dibble \& Meredith Jung-En Woo 2006. German Kim of the Kazakh State University is the historical consultant. Koryo Saram - The Unreliable People (documentary film - one hour) 2006. 
Ryazantsev, S. 2013. Russia Needs a New Migration Policy. In the: Russian Politics and Low, Volume 51, Number 3, May-June 2013. pp. 80-88.

Mishchuk, S.N. 2013. Domestic and International Migration in the Russian Far Eastin the Mid 19th-Early 21st Century. In the: Regional Research of Russia. Vol. 3, No. 4, pp. 348-355.

Chzhon, Bon Su. 2011. Migratsiya koreytsev v Rossiyskuyu imperiyu vo vtoroy polovine XIX v. eyo sotsialno-ekonomocheskie predposylki. In the: Vlast, \#12. pp. 173-176.

Pak, B.D. 1993. Koreytsy v Rossiyskoy imperii (Dalnevostochnyi period). M., MGU.

Petrov, A.I. 2000. Koreyskaya diaspora na Dalnem Vostoke Rossii. 60-90 gg. XIX v. Vladivostok.

Kyuner, N.V. 1912. Statistiko-geograficheskiy i economicheskiy ocherk Korei, nyne yaponskogo general-gubernatorstva Tsiosen. Vypusk 1. Vladivostok, izdatelstvo Vostochnogo instituta.

Bayov, A. 1904. Voenno-geograficheskiy I statisticheskiy ocherk Severnoy Korei. Voenno-statisticheskiy otdel Glavnogo shtaba. SanktPeterburg, 1904.

Lesa Priamurskogo kraya. 1883. Sbornik glavneyshich ofitsialnych dokumentov po upravleniyu Vostochnoy Sibiriyu. Tom V. Vipusk 1. Opisanie lesov Primorskoy oblasti. Irkutsk.

Oh Hong-seok. 2009. Traditional Korean Villages. Seoul. pp. 97-101.

Nadarov, I. 1886. Proizvodstvo I potreblenie chanshina (kitaiskoy vodka) v Ussuriyskoy strane (Severno- i Yuzhno-Ussuriyskom krae. Inorodcheskoe naselenie Ussuriyskoy straini. In the: Materialy k izucheniyu Ussuriyskogo kraya. Doklady v Obshchestve izucheniya Amurskogo kraya. Vladivostok.

Naselennye I zhilye mesta Primorskogo rayona, 1915. Krestiyane, inorodtsy, zheltye. Perepis naseleniya 1-20 iyunya 1915. Ministerstvo zemledeliya. Primorskiy pereselencheskiy rayon. Statisticheskiy otdel. Vladivostok.

Wrangham, R. 2009. Catching fire: how cooking made us human Basic Books NY, 2009.

Pereselenie russkich lyudey v Priamurskiy krai, 1884. Sbornik glavneyshich ofitsialnych dokumentov po upravleniyu Vostochnoy Sibiriyu. Tom II. Vipusk 3. O krugosvetnom pereselenii v Yuzhno-Ussuriyskiy krai i ustroystve tam 1-y partii pereselentsev, otpravlennych iz Odessy v 1883 godu. Irkutsk.

Ionova, Yu.V. 1960. Koreiskaya derevnya v kontse XIX I nachale XX v. In the: Vostochno-Asiatsky etnograficheskii sbornik. Izdatelstvo Akademii nauk SSSR. - M.-L.

Lankov, A. 2015. Korea: strana i lyudi- http://lankov.oriental.ru/203.shtml.

CIA. The world factbook 2014 / Sex ratio - https://www.cia.gov/library/publications/the-world-factbook/fields/2018.html.

Azbelev, I.P. 1895. Yaponiya i Koreya. Zametki iz krugosvetnogo plavaniya. Moskva. Izdanie tovarishchestva A.A.Levenson.

Ryazantsev, S.V., Pismennaya, E.E., Karabulatova I.S. \& Charif Y. Akramov 2014. Transformation of sexual and matrimonial behavior of Tajik labor migrants in Russia. In the: Asian Social Science. Vol 10, No.20, 2014.

Karabulatova, I.S., Koyche K..K. \& Gultyaev V.N. 2013. The Dialogue of Kazakh Steppe and Russian Forest: About the Character of Turkic-Speaking Linguistic Personality on the Territory of Russian-Kazakhstani Border-Zone. In the: Middle-East Journal of Scientific Research 17 (7). pp. 853-858.

Karabulatova, I.S. 2013. The problems of linguistic modeling of new Eurasian linguistic personality in multilinguistic and mental environment (by example of onomasphere). In the: Middle-East Journal of Scientific Research 17 (6). pp. 791-795.

Karabulatova, I.S., Polivara Z.V. 2013. Turkic and Slavs: bi-polylinguism in globalization and migrations (on an example of Tumen region). In the: Middle-East Journal of Scientific Research 17 (6). pp. 832-836.

Ryazantsev, S.V. 2014. The lingual integration of migrants in Russia: declarations and realities. In the: Life Science Journal, 2014, \# 11(8s). pp: 139-143. 
ISSN 2039-2117 (online) ISSN 2039-9340 (print)
Mediterranean Journal of Social Sciences MCSER Publishing, Rome-Italy
Vol 6 No 3 S4 May 2015 